\title{
Learning Cycle-6e and Cognitive Conflict Strategies: The Remedial Learning to Overcome Misconceptions
}

\author{
Rolisonia Rona Kecima Jeharut ${ }^{\mathrm{a}, 1}$, Subandi ${ }^{\mathrm{b} *}$, Habiddin Habiddin ${ }^{\mathrm{b}}$ \\ ${ }^{a}$ Department of Chemistry Education, Postgraduate Program, Universitas Negeri Malang, Indonesia \\ ${ }^{b}$ Department of Chemistry, Faculty of Mathematics and Natural Sciences, Universitas Negeri Malang, Indonesia \\ ${ }^{1}$ subandi.fmipa@um.ac.id* \\ * corresponding author
}

\begin{abstract}
\begin{tabular}{l|l} 
ARTICLE INFO ABSTRACT &
\end{tabular}
Article history

Received 06, 09, 2020

Revised 08, 11, 2020

Accepted 08, 22, 2020

Keywords

Learning cycle-6E

Cognitive conflict strategy

Misconceptions

Acid-base

The purposes of this study were: 1) to identify students' misconceptions on acidbase concepts 2) to examine the effectiveness of the Learning Cycle-6E models and cognitive conflict strategies in overcoming students' misconceptions and 3) to measure the retention of students' understanding of the concept. A descriptive and pre-experimental design with one group pretest-posttest design was employed in the study. Thirty secondary school students from a public school in the province of Nusa Tenggara Timur, Indonesia were recruited. A three-tier instrument was applied to reveal students' misconceptions as well as their scientific understanding. A paired t-test statistical procedure was also applied to uncover the effectiveness of the Learning Cycle-6E and cognitive conflict strategies. The students' conceptual retention was measured in 3 weeks after the intervention (the implementation of Learning Cycle-6E models and cognitive conflict strategies). Findings suggested that several students' misconceptions about the topic of acid-base have been uncovered. Also, our study portrayed that Learning Cycle-6E and cognitive conflict strategies are prevailing in reducing the students' misconceptions. This paper highlights that retention of students' scientific understanding after treatment were very good.

Tujuan dari penelitian ini adalah untuk 1) mengidentifikasi miskonsepsi siswa tentang konsep asam basa 2) menguji keefektifan model Learning Cycle-6E dan strategi konflik kognitif dalam mengatasi miskonsepsi siswa dan 3) mengukur retensi pemahaman konsp siswa. Desain deskriptif dan pra-eksperimental dengan desain satu kelompok pretest-posttest digunakan dalam penelitian ini terhadap 30 siswa sekolah menengah dari sekolah negeri di provinsi Nusa Tenggara Timur, Indonesia. Instrumen three-tier diterapkan untuk mengetahui kesalahpahaman serta pemahaman ilmiah siswa. Prosedur statistic t-test berpasanagn diterapkan untuk mengetahui efektivitas model Learning Cycle-6E dan strategi konflik kognitif. Retensi konseptual siswa diukur 3 minggu setelah intervensi (penerapan model pembelajaran Learning Cycle-6E dan strategi konflik kognitif). Hasil penelitian menunjukan bahwa ditemukan beberapa kesalahpahaman siswa dalam topik asam-basa. Selain itu, terbukti bahwa Learning Cycle-6E dan strategi konflik kognitif sangat efektif dalam mengurangi kesalahpahaman. Hasil ini juga menunjukkan bahwa retensi pemahaman ilmiah siswa setelah perlakuan termasuk dalam kategori sangat baik.
\end{abstract}

This is an open access article under the $\mathrm{CC}-\mathrm{BY}$ license.

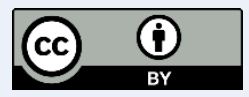

\section{Introduction}

Recently, research in chemistry education has revealed that many students have an understanding or conception that is not accordance with scientific concepts, or the concepts of truth recognized by scientific community (Gegios et al., 2017), further known as misunderstanding or misconcep-tions (Muchtar, 2012; Sendur et al., 2010). Misconceptions in chemistry concepts have been extensively studied, including acid-base concepts. Some alternative conceptions are generally related to topics such as $\mathrm{pH}$, conjugate 
acid-base pairs, salt, neutralization, titration and buffer solutions (Artdej et al., 2010; Damanhuri et al., 2016; Demircioğlu et al., 2005)

Misconceptions are obstacles to success in the learning process (Garnett et al., 1995) since resistance tend to be maintained by students. Therefore, the number of students experiencing misconceptions should be reduced (Suyono, 2020) by being identified continuously to create a learning environment in order to overcome these misconceptions (Kırık \& Boz, 2012). Although the identification of misunderstandings included in acid-base material has been widely carried out, it was unfollowed with efforts to surmount or reduce these misconceptions, whereas knowledge about misconceptions is an asset for teachers to design the learning process (Pan \& Henriques, 2015). Thus, the identification of misconceptions should be followed by the efforts or treatments to unravel the misconceptions.

The identification of misconceptions cannot be carried out using conventional learning assessment instruments such as multiple choice. Therefore, many researchers use multi-tier diagnostic instruments, especially four-tier instruments (Habiddin \& Page, 2019). Multi-tier instruments including two-tier, three-tier and fourtier levels have been developed and used to identify the understanding of concepts in several chemistry topics, including chemical kinetics (Habiddin \& Page, 2019; Yan \& Subramaniam, 2018), chemical equilibrium (Dewi et al., 2020), thermodynamics (Sreenivasulu \& Subramaniam, 2013), transition metal chemistry (Sreenivasulu \& Subramaniam, 2014), and the acid-base characteristic of salt solutions (Habiddin et al., 2020; Husniah et al., 2019)

The source of misconceptions is not only caused by students' prior knowledge that is intuitive but also because of inappropriate learning strategies, commonly known as school-made misconceptions (Barke et al., 2008). The efforts to improve students' understanding of concepts and alleviate students' misconceptions have been carried out by using various learning strategies, including reciprocal teaching on acid-base material (Maysara \& Habiddin, 2019), the text of the conceptual change and experiments on topics and their transformations and physical inorganic chemistry (Durmuş \& Bayraktar, 2010; Rohmah et al., 2020) excel-based modelling (Malone et al., 2018), and concept-oriented learning change on gas topics (Cetin et al., 2009)

The efforts to overcome misconceptions can be carried out on regular and remedial learning.
Learning Cycle-6E is a learning model that refers to a constructivist approach that is believed to be able to create a precise learning environment to reduce and overcome students' misconceptions. The Learning Cycle model is stages of activities designed that engage students to effortlessly master the competencies achieved through playing an active role in the learning process (Ngalimun, 2016). The steps in the Learning Cycle- 6E model are very detailed in that students' mindset becomes more structured and systematic and makes them easily understand and remember the material learned during the learning process (Yulianingtyas et al., 2017). The phases in the Learning Cycle-6E model begins with (1) elicit phase (identification) in the form of delivering learning purposes that aim to make students more focused on the learning purposes and actively involved during the learning process, (2) the engagement phase (invitation phase), (3) exploration phase, (4) explanation phase (exploration phase), (5) elaboration phase and (6) evaluation phase -These learning processes are attractive because students' experiences in trying to find concepts will be internalized and remembered for the long term.

Besides, the effort to correct misconceptions is by reconstructing students' understanding. Therefore, it is necessary to combine the learning model of Learning Cycle-6E with a learning strategy that has steps to retrieve misconceptions. The intended learning strategy is a cognitive conflict strategy, which is a conceptual alteration strategy to change the wrong concept towards a conception following scientific concepts (Irawati \& Ali, 2018). Previous research conducted by (Effendy, 2002; Madu \& Orji, 2015; Rahayu et al., 2011) showed that the cognitive conflict learning process can help reconstruct students' understanding and engages students to correlate the previous knowledge that they have understood with new knowledge that they will learn. Thus, the main objective of this study is to describe how remedial learning using Learning Cycle-6E and cognitive conflict strategies can reduce students' misconceptions. This research can also depict new perspectives for correcting inaccurate use of the term remedial, which is often interpreted as a retest in learning.

\section{Method}

This study employed descriptive and pre-experimental designs with One-Group PretestPosttest Design to describe misconceptions and retention of conceptual understanding of the students of Kefamenanu 2 Public High School 
using a three-tier diagnostic test. Meanwhile, the pre-experimental design was used to determine the effectiveness of learning using the Learning Cycle-6E model and the Cognitive Conflict Strategy by comparing student test results before (pretest) and after treatment (posttest). An overview of pre-experimental research designs is shown in Table 1.

Table 1. Research Design Scheme

\begin{tabular}{cccc}
\hline Category & $\begin{array}{c}\text { Pretest }(\text { di- } \\
\text { agnostic } \\
\text { test })\end{array}$ & $\begin{array}{c}\text { Treat } \\
\text { ment }\end{array}$ & $\begin{array}{c}\text { Post- } \\
\text { est }\end{array}$ \\
\hline $\begin{array}{c}\text { Experimental } \\
\text { Class }\end{array}$ & $\mathrm{O}_{1}$ & $\mathrm{X}$ & $\mathrm{O}_{2}$ \\
\hline
\end{tabular}

\section{Tabel description:}

$X$ : Refinement learning using the Learning Cycle$6 E$ model and cognitive conflict strategies

O1: Preliminary tests conducted before learning using the Learning Cycle-6E model and Cognitive Conflict Strategy

O2: The final test (posttest) carried out after learning using the Learning Cycle-6E model and the Cognitive Conflict Strategy

The research included five stages: Pretest (initial test), Interview, Treatment using the combination of Learning Cycle-6E with the Cognitive Conflict Strategy, Post-test (final test), Delayed tests three weeks after treatment.

Participants involved in this study were 30 students of class eleven in the Science Program 3 of Kefamenanu 2 Public High School, who had studied acid-base topic. They were recruited using a convenience sampling technique, considering the ease of researchers in collecting data. In this study, all participants attended the remedial learning. The three-tier instrument was adapted and modified from (Fitri, 2017) that was used to identify students' misconceptions. This instrument encompasses superior reliability. The results of students' misconceptions identification were then followed with interviews. Nine participants were invited to attend an interview session after the pretest comprising of students from the group with low pretest scores, and three students from the group with average scores, and three students from the group with high pretest scores.

Student misconceptions were categorized using CRI criteria (level of certainty in answering questions) shown in Table 2.

\begin{tabular}{cc}
\hline CRI & Criteria \\
\hline 0 & totally guessed \\
1 & almost guessed \\
2 & not sure \\
3 & sure \\
4 & almost certain/almost confident \\
5 & certain/confident \\
\hline
\end{tabular}

The categories of students who understand concepts, misconceptions, and do not understand them are based on criteria according to Table 3 .

Table 3. The Criteria of CRI Conditions for Students' Answers

\begin{tabular}{|c|c|c|c|}
\hline Answer & Reason & $\begin{array}{l}\text { CRI } \\
\text { Score }\end{array}$ & Categories \\
\hline Correct & Correct & $>2.5$ & $\begin{array}{l}\text { Understand the } \\
\text { concept well }\end{array}$ \\
\hline Correct & Correct & $<2.5$ & $\begin{array}{l}\text { Understand the } \\
\text { concept but not } \\
\text { confident with the } \\
\text { answers }\end{array}$ \\
\hline Correct & Incorrect & $>2.5$ & Misconception \\
\hline Correct & Incorrect & $<2.5$ & $\begin{array}{l}\text { Do not understand } \\
\text { the concept }\end{array}$ \\
\hline Incorrect & Correct & $>2.5$ & Misconception \\
\hline Incorrect & Correct & $<2.5$ & $\begin{array}{l}\text { Do not understand } \\
\text { the concept }\end{array}$ \\
\hline Incorrect & Incorrect & $>2.5$ & Misconception \\
\hline Incorrect & Incorrect & $<2.5$ & $\begin{array}{l}\text { Do not understand } \\
\text { the concept }\end{array}$ \\
\hline
\end{tabular}

The effectiveness of the Learning Cycle-6E model and cognitive conflict strategy was determined by comparing the number of students who experienced misconceptions at the pretest (before treatment) and posttest (after treatment). T-test was conducted to see the significance of the difference between the result of pretest and posttest. Besides, a delayed test was conducted to see the retention or endurance of students in maintaining an understanding of acid-base material after treatment with a certain time interval. In this study, the delayed test was carried out in 3 weeks after treatment. Pretest, posttest, and delayed test instruments were used to minimize the possibility of students in memorizing the answers without understanding the concept correctly. The researcher randomized the order of questions, choice of answers, and the choice of the reasons.

Table 2. CRI Scores (Certainty of Response Index) and The Criteria 


\section{Results and Discussion}

Based on the pattern of students' answers, three emerging themes were found, namely, A) types of students' misconceptions on acid-base material, B) the effectiveness of the use of Learning Cycle-6E models and cognitive conflict strategies in decreasing student misconceptions, and C) retention of students' conceptual understanding three weeks after treated (the delayed test).

\section{A. Types of students' misconceptions}

The pattern of students 'answers from the pretest documented 37 types of students' misconceptions spreading over five sub-topics of acid-base. The types of students' misconceptions on acid-base topic during the pretest is shown in Table 4.

Table 4. Types of Misconceptions on Acid-Base Topic (Pretest Result)

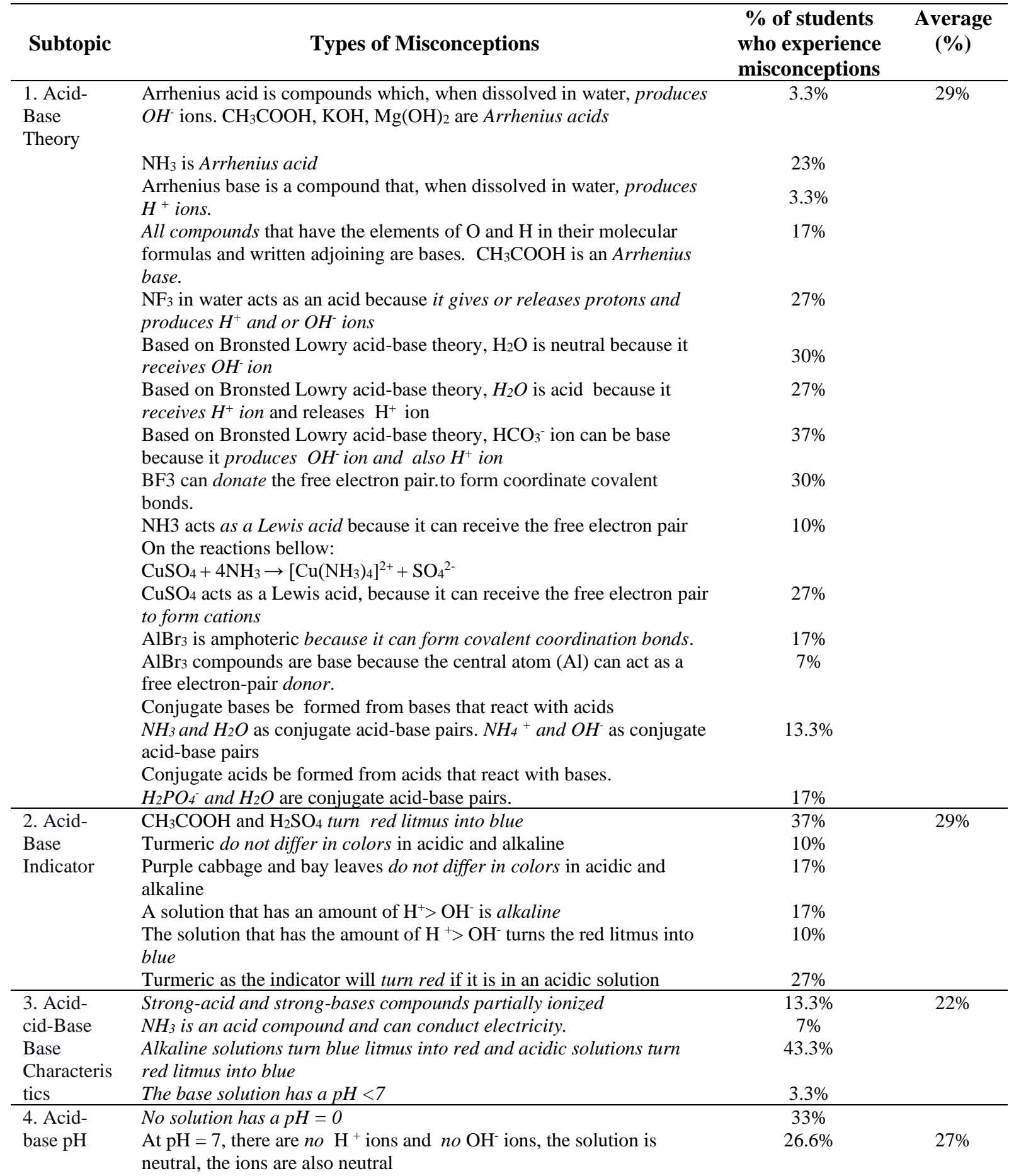




\begin{tabular}{|c|c|c|c|}
\hline Subtopic & Types of Misconceptions & $\begin{array}{c}\% \text { of students } \\
\text { who experience } \\
\text { misconceptions }\end{array}$ & $\begin{array}{c}\text { Average } \\
(\%)\end{array}$ \\
\hline \multirow[t]{6}{*}{$\begin{array}{l}\text { and } \\
\text { Strength }\end{array}$} & $\begin{array}{l}\mathrm{pH} \text { is a positive function of } \mathrm{H}^{+} \text {ion concentration and a negative } \\
\text { function of the } \mathrm{OH}^{-} \text {ion concentration logarithm }\end{array}$ & $30 \%$ & \\
\hline & $\mathrm{H}_{3} \mathrm{PO}_{4}$ is a stronger acid than $\mathrm{HCl}$ because $\mathrm{H}_{3} \mathrm{PO}_{4}$ more ionized & $40 \%$ & \\
\hline & The more H atoms in the acid formula, the acidic is stronger & $20 \%$ & \\
\hline & The smaller of $\mathrm{Ka}$, the acidic is stronger & $17 \%$ & \\
\hline & The smaller $\mathrm{Kb}$, the base is stronger & $33 \%$ & \\
\hline & $\mathrm{HCl}$ and $\mathrm{H}_{2} \mathrm{SO}_{4}$ are not include in Arrhenius acid & $23 \%$ & \\
\hline \multirow{4}{*}{$\begin{array}{l}\text { 5. Acid- } \\
\text { Base } \\
\text { Reactions } \\
\text { (Neutralizat } \\
\text { ion) } \\
\end{array}$} & The results of the neutralization reaction are always at $\mathrm{pH}=7$ & $37 \%$ & $33 \%$ \\
\hline & The reaction between acids and bases only produces salt & $7 \%$ & \\
\hline & The reaction between acids and bases is always neutral & $23 \%$ & \\
\hline & Average Total & & $28 \%$ \\
\hline
\end{tabular}

Table 4 shows that the average percentage of students' misconceptions on acid-base topic was $28 \%$ and classified as low misconception. The highest percentage found in the sub-topic of Acid Base Reaction is $33 \%$, while the lowest percentage is in the subtopic of characteristics of acid-base solutions $(22 \%)$. The detail percentages of students' understanding before treatment (pretest) is briefly shown in Fig. 1.

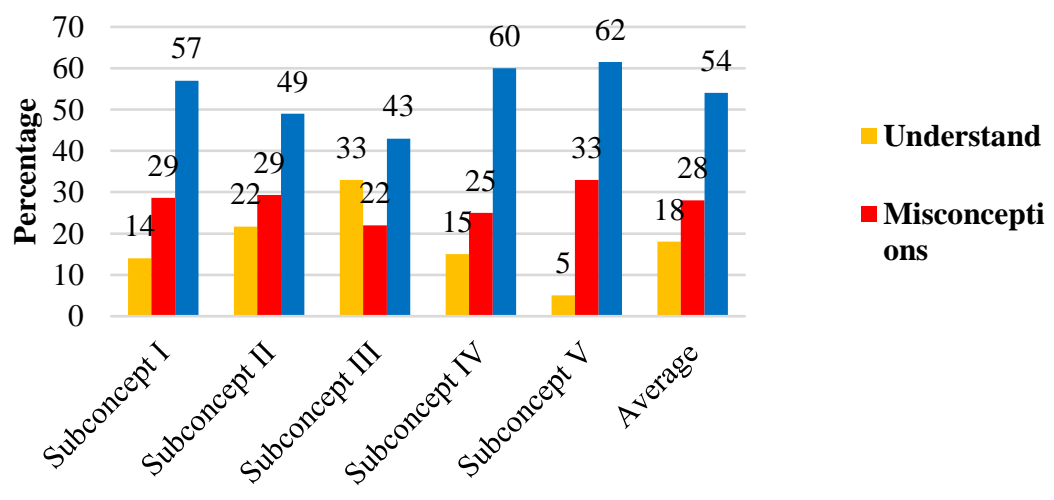

Percentage of Student's Understanding (Pretest result) on each Subtopic (Subconcept)

The percentage of students who understood the concept, experienced misconceptions, and did not understand the concept were $18 \%, 28 \%$, and $54 \%$, respectively.

\section{B. The Effectiveness of the Cycle-6E \\ Learning Model and the Cognitive Conflict Strategy}

The percentage of students' misconceptions after remedial learning using the Learning $\mathrm{Cy}$ cle-6E model and cognitive conflict strategies decreased to $14 \%$. The complete data are presented in appendix 2 . The results of the percentage of students' understanding after remedial (posttest) is shown in Fig 2.

Fig. 2 reveals that most of the students already understand the concepts as shown by the high average by $72 \%$. In comparison, only a few of them experience misconceptions indicated by $14 \%$, and the remaining $15 \%$ of students do not understand the concepts. 


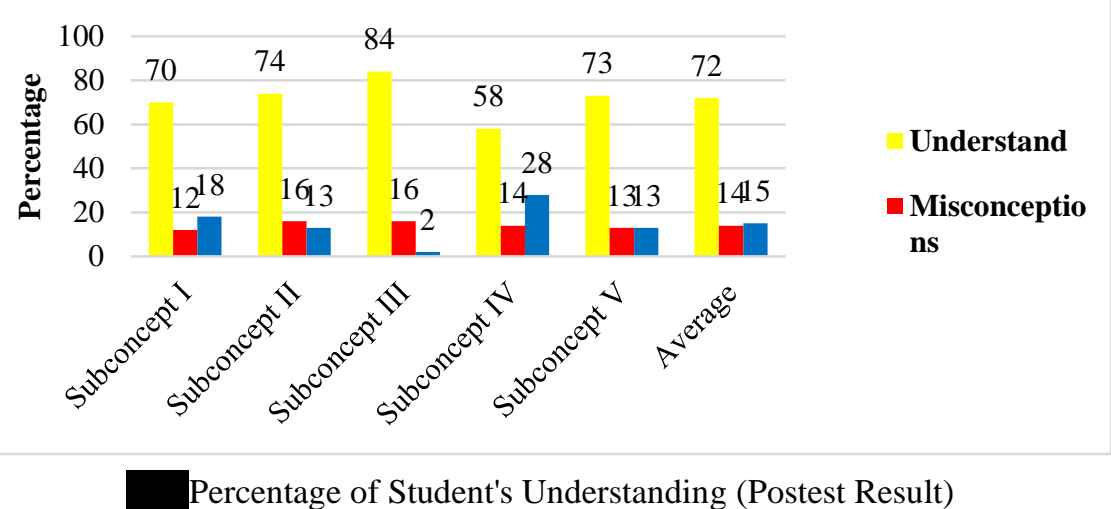

Fig. 2 shows that $72 \%$ of students have a correct understanding of the concept, $14 \%$ are still experiencing misconceptions, and $15 \%$ do not understand the concept. The t-test results also showed that there are significant differences between the scores of students before and after being treated using the Learning Cycle-6E model and cognitive conflict strategies. The conclusion is that the Learning Cycle- $6 \mathrm{E}$ model and the Cognitive Conflict Strategy can effectively reduce students' misconceptions on acid-base material.

\section{The Retention of Students' Concepts Understanding}

The delayed tests were conducted to determine the retention (resistance) of students' understanding of acid-base material three weeks after treatment (remedial learning). A student's retention score is a comparison between the number of questions that were answered correctly on the delay test and on the post test, as can be seen on Table 5 .

Table 5. The Retention of Students Understanding

\begin{tabular}{|c|c|c|c|c|}
\hline \multirow{2}{*}{ Students' ID } & \multicolumn{2}{|c|}{ Number of question items answered correctly } & \multirow{2}{*}{$\%$ Retention } & \multirow{2}{*}{ Categories } \\
\hline & Postest & Delayed Test & & \\
\hline 1 & 24 & 21 & 88 & Very Good \\
\hline 2 & 8 & 8 & 100 & Very Good \\
\hline 3 & 14 & 10 & 71 & Good \\
\hline 4 & 16 & 13 & 81 & Very Good \\
\hline 5 & 17 & 14 & 82 & Very Good \\
\hline 6 & 19 & 17 & 89 & Very Good \\
\hline 7 & 21 & 17 & 81 & Very Good \\
\hline 8 & 23 & 18 & 83 & Very Good \\
\hline 9 & 19 & 16 & 84 & Very Good \\
\hline 10 & 21 & 19 & 90 & Very Good \\
\hline 11 & 17 & 15 & 88 & Very Good \\
\hline 12 & 19 & 15 & 79 & Good \\
\hline 13 & 17 & 16 & 94 & Very Good \\
\hline 14 & 25 & 23 & 92 & Very Good \\
\hline 15 & 27 & 24 & 89 & Very Good \\
\hline 16 & 21 & 18 & 81 & Very Good \\
\hline 17 & 23 & 20 & 87 & Very Good \\
\hline 18 & 21 & 20 & 95 & Very Good \\
\hline 19 & 23 & 22 & 96 & Very Good \\
\hline 20 & 22 & 21 & 95 & Very Good \\
\hline 21 & 20 & 19 & 95 & Very Good \\
\hline 22 & 24 & 21 & 88 & Very Good \\
\hline 23 & 22 & 20 & 91 & Very Good \\
\hline 24 & 21 & 19 & 90 & Very Good \\
\hline 25 & 22 & 20 & 91 & Very Good \\
\hline 26 & 22 & 20 & 91 & Very Good \\
\hline 27 & 25 & 19 & 76 & Good \\
\hline 28 & 16 & 15 & 94 & Very Good \\
\hline 29 & 24 & 21 & 88 & Very Good \\
\hline 30 & 16 & 11 & 69 & Pass \\
\hline \multicolumn{3}{|c|}{ Average } & $87 \%$ & Very Good \\
\hline
\end{tabular}




\section{Types of Student Misconceptions}

The dominant misconceptions showed by students based on the pretest results (before the remedial implementation) are presented below:

\section{1) Sub topic of Acid-Base Theory}

The acid-base theory discussed theory of Arrhenius, Bronsted-Lowry, and Lewis. Based on the results of the pretest, we found 16 types of misconceptions in $29 \%$ of students. The most common misconception experienced by students is " $\mathrm{HCO}_{3}$ ' ions can be base because they can receive $\mathrm{OH}$ ions and can also produce $\mathrm{H}^{+}$ ions". This finding is similar to previous research carried out by (Artdej et al., 2010) who found that "Bronsted Lowry acid can accept electron pairs or produce $\mathrm{H}^{+}$ions." Besides, (Bayrak, 2013; Muchtar, 2012) documented another misconception such as "all compounds containing $\mathrm{H}^{+}$ions in the structure are Arrhenius acids and those containing $\mathrm{OH}$ - ions in the structure are Arrhenius bases." Therefore, this finding encourages teachers to emphasize the characteristics of each acid-base theory.

A misconception that is also experienced by many students in our study is "Conjugate acids formed from acids react with bases. $\mathrm{H}_{2} \mathrm{PO}_{4}$ and $\mathrm{H}_{2} \mathrm{O}$ are conjugate acid-base pairs.". This phenomenon shows that students do not understand well the basic principles of conjugate acids and conjugate bases. This result is in accordance with (Lathifa, 2018) study who revealed that "conjugate acids are acids formed from acids react with bases while conjugate bases are bases from bases react with acids." Besides, (Labobar et al., 2017; Rahayu et al., 2011) portrayed that students believed "conjugated acid as an anion of its acid, meanwhile conjugate base as a cation of its base". Meanwhile, Embisa and Fajaroh (2019) found that in the reaction of $\mathrm{HCN}(a q)+$ $\mathrm{H}_{2} \mathrm{O}(l) \rightarrow \mathrm{H}_{3} \mathrm{O}+(a q)+\mathrm{CN}^{-}(a q)$, then $\mathrm{H}_{3} \mathrm{O}^{+}$ acts as a base ", and " $\mathrm{H}_{3} \mathrm{O}^{+}(a q)$ and $\mathrm{CN}^{-}(a q)$ is a conjugate acid-base pair.

\section{2) Sub topic of Acid-Base Indicator}

The significant misconception experienced by students on this concept is " $\mathrm{CH}_{3} \mathrm{COOH}$ and $\mathrm{H}_{2} \mathrm{SO}_{4}$ are acidic solutions which turn red litmus into blue". This finding is in line with previous research carried out by (Embisa et al., 2019) who portrayed that "sulfuric acid is acidic that turn red litmus paper into blue." This phenomenon shows that students do not understand the change in color of the indicator that shows the acidity or basicity of a solution.

3) Subconcepts of Acid-base $p H$ and AcidBase Strength
On this topic, 8 types of misconceptions were found in $25 \%$ of students. The notable type experienced is " $\mathrm{H}_{3} \mathrm{PO}_{4}$ is stronger acid than $\mathrm{HCl}$ because $\mathrm{H}_{3} \mathrm{PO}_{4}$ has more $\mathrm{H}$ atoms, $\mathrm{H}_{3} \mathrm{PO}_{4}$ is more ionized and has a smaller Ka." This finding is similar to what have been revealed by (Amry et al., 2017; Cetingul \& Geban, 2005; Demircioğlu et al., 2005; Lathifa, 2018). They uncovered a conception such as "the more Hatoms in the formula of an acid compound, the acid will be stronger." Misconceptions occur because students misunderstand that "the strength of acids and bases is determined by the ability of acids to dissociate or ionize. The stronger the ionization of acid results higher-amount of $\mathrm{Ka}$ and the higher-strength of the acid."

Another misconception found was "no solution has a $\mathrm{pH}=\mathrm{O}^{\prime}$. This is in line with a previous study done by (Cetingul \& Geban, 2005), who found that "solutions with $\mathrm{pH}=0$ cannot include in either acidic or basic solutions." Misconceptions that occur can be caused by students who do not understand that if $\mathrm{pH}=0$, it means the concentration of $\mathrm{H}+$ is $1 \mathrm{M}$

\section{4) Sub topic of Acid-Base Reactions (Neutralization)}

In this subtopic, we found three types of misconceptions in 33\% of students. The significant misconception experienced is "the results of the neutralization reaction always have a $\mathrm{pH}=7$." This result is in accordance with the work of (Cetingul \& Geban, 2005), that "the results of acid-base reactions always produce neutral solutions." This may be because students do not understand the occurrence of hydrolysis in salt so that the result of the neutralization reaction does not always produce $\mathrm{pH}=7$

\section{E. Effectiveness of the Cycle-6E Learning Model and Cognitive Conflict Strategies}

The effectiveness of the Learning Cycle-6E model and the Cognitive Conflict Strategy in decreasing misconceptions experienced by students on acid-base topic can be seen from the results of the pre-test and post-tests. After improvements were made using the Learning $\mathrm{Cy}$ cle-6E learning model and cognitive conflict strategies, students' misconceptions decreased from an average of 28 to $14 \%$. This remedial teaching and learning help students understand the right concepts following scientific concepts and be aware of their concept errors. The stages of this model carried out by appearing students' dissatisfaction with their wrong concepts follows the requirements of the concept change raised by Piaget, and the stages of learning can engage the students in meaningful learning. 
Meaningfulness is felt by students if the concepts they have acquired are correct and can be applied to solve other problems.

The effectiveness of this remedial learning is strengthened statistically using t-test, which shows that there is a significant difference between the pre-test score and the post-tests score. These results reinforce the same report by (Labobar et al., 2017; Rahayu et al., 2011). This means that learning using the Learning Cycle$6 \mathrm{E}$ model, and the Cognitive Conflict Strategy not only decrease misconceptions but also improves students' understanding.

\section{F. The Retention of Students' Understanding the Concept in Three Weeks after \\ Treatment}

The learning Cycle-6E model and cognitive conflict strategies are also proven to help students maintain their conceptual understandings of acid-base material they have learned. The average percentage of student retention on acid-base concepts after three weeks of treatment was $87 \%$ and classified as very good criteria. The high retention shows that most students are considered able to maintain the understanding of concepts in acid-base material that they have learned three weeks after treatment. These results align with the findings of (Lathifa, 2018), where the average retention of students' conceptual understandings is $92 \%$, and (Embisa et al., 2019) who documented 87\% of average retention. (Hameed et al., 1993) previously explained that students who completely replaced the wrong concept with the correct one following the scientific concept and could maintain the right concept, showing that students have a high retention of conceptual understanding. Besides, (Anderson et al., 1977) suggested that one of the factors of the high retention of students' conceptual understandings is also caused by students' consistency in maintaining the concepts that they believe to be correct.

\section{Conclusion}

The results of this study indicate that students still experience a lot of misconceptions about acid-base material with a sizable percentage (28\%). The misconceptions spread over five subtopics with acid-base theory is $29 \%$, acidbase indicators are $29 \%$, characteristics of acidbase solutions is $22 \%, \mathrm{pH}$ and acid-base strength is $25 \%$, and acid-base reaction (neutralization) is $33 \%$. Remedial teaching-learning using the Learning Cycle-6E model and cognitive conflict strategies have been proven to be considerably effective in decreasing students' misconceptions. The retention of students' understanding in three weeks after treatment was $87 \%$ and classified as very good. However, further research is needed to ascertain whether the retention can survive in students' long-term memory by conducting a delayed test with a lengthy period.

\section{References}

Amry, U. W., Rahayu, S., \& Yahmin, Y. (2017). Analisis miskonsepsi asam basa pada pembelajaran konvensional dan Dual Situated Learning Model (DSLM). Jurnal Pendidikan, 2(3), 385-391. https://doi.org/10.17977/jptpp.v2i3.8636

Anderson, R. C., Reynolds, R. E., Schallert, D. L., \& Goetz, E. T. (1977). Frameworks for comprehending discourse. American Educational Research Journal, 14(4), 367-381.

Artdej, R., Ratanaroutai, T., Coll, R. K., \& Thongpanchang, T. (2010). Thai grade 11 students' alternative conceptions for acidbase chemistry. Research in Science and Technological Education, 28(2), 167-183. https://doi.org/10.1080/026351410037483 82

Barke, H. D., Hazari, A., \& Yitbarek, S. (2008). Misconceptions in chemistry: Addressing perceptions in chemical education. Springer Science \& Business Media.

Bayrak, B. K. (2013). Using two-tier test to identify primary students' conceptual understanding and alternative conceptions in acid base. Mevlana International Journal of Education, 3(2), 19-26. https://doi.org/10.13054/mije.13.21.3.2

Cetin, P. S., Kaya, E., \& Geban, Ö. (2009). Facilitating conceptual change in gases concepts. Journal of Science Education and Technology, 18(2), 130-137. https://doi.org/10.1007/s10956-008-9138-y

Cetingul, P. I., \& Geban, O. (2005). Understanding of acid-base concept by using conceptual change approach. Hacettepe University Journal of Education, 29, 69-74.

Damanhuri, M. I. M., Treagust, D. F., Won, M., \& Chandrasegaran, A. L. (2016). High school students' understanding of acid-base concepts: An ongoing challenge for teachers. International Journal of Environmental and Science Education, 11(1), 9-27. https://doi.org/10.12973/ijese.2015.284a

Demircioğlu, G., Ayas, A., \& Demircioğlu, H. (2005). Conceptual change achieved through a new teaching program on acids and bases. Chemistry Education Research and Practice, 6(1), 36-51. https://doi.org/10.1039/B4RP90003K. 
Dewi, F. C., Parlan, P., \& Suryadharma, I. B. (2020). Development of four-tier diagnostic test for identifying misconception in chemical equilibrium. AIP Conference Proceedings, 2215(1), 020004. https://doi.org/10.1063/5.0000510

Durmuş, J., \& Bayraktar, Ş. (2010). Effects of conceptual change texts and laboratory experiments on fourth grade students' understanding of matter and change concepts. Journal of Science Education and Technology, 19(5), 498-504. https://doi.org/10.1007/s10956-010-9216-9

Effendy, E. (2002). Upaya mengatasi kesalahan konsep dalam pembelajaran kimia dengan menggunakan strategi konflik kognitif. Jurusan Kimia FMIPA Universitas Negeri Malang (UM), 6(2), 1-17.

Embisa, A. A., Subandi, S., \& Fajaroh, F. (2019). Misconception of high school students on acid-base topics and effectiveness of argument-driven inquiry learning. Jurnal Pendidikan Sains, 7(3), 103-110.

Fitri, S. (2017). Dampak positif dan negatif sosial media terhadap perubahan sosial anak: dampak positif dan negatif sosial media terhadap perubahan sosial anak. Naturalistic: Jurnal Kajian Penelitian Pendidikan Dan Pembelajaran, 1(2), 118123.

Garnett, P. J., Garnett, P. J., \& Hackling, M. W. (1995). Students' alternative conceptions in chemistry: a review of research and implications for teaching and learning. Studies in Science Education, 25(1), 69-96. https://doi.org/10.1080/030572695085600 50

Gegios, T., Salta, K., \& Koinis, S. (2017). Investigating high-school chemical kinetics: The Greek chemistry textbook and students' difficulties. Chemistry Education Research and Practice, 18(1), 151-168.

Habiddin, H., Ameliana, D. N., \& Su'aidy, M. (2020). Development of a Four-Tier Instrument of Acid-Base properties of salt Solution. JCER (Journal of Chemistry Education Research), 4(1), 51-57. https://doi.org/10.26740/jcer.v4n1.p51-57

Habiddin, H., \& Page, E. M. (2019). Development and validation of a four-tier diagnostic instrument for chemical kinetics (FTDICK). Indonesian Journal of Chemistry, 19(3), 720-736. https://doi.org/10.22146/ijc.39218

Hameed, H., Hackling, M. W., \& Garnett, P. J. (1993). Facilitating conceptual change in chemical equilibrium using a CAI strategy. International Journal of Science Education, 15(2), 221-230. https://doi.org/10.1080/0950069930150209

Husniah, I., Habiddin, H., Sua'idy, M., \& Nuryono, N. (2019). Validating an instrument to investigate students' conception of Salt hydrolysis. Journal of
Disruptive Learning Innovation (JODLI), 1(1), 1-6.

Irawati, Z. C., \& Ali, R. M. (2018). Cognitive conflict strategy to minimize students , misconception on the topic of addition of algebraic expression Cognitive conflict strategy to minimize students misconception on the topic of addition of algebraic expression. Journal of Physics: Conference Series.

Kırık, Ö. T., \& Boz, Y. (2012). Cooperative learning instruction for conceptual change in the concepts of chemical kinetics. Chemistry Education Research and Practice, 13(3), 221-236. https://doi.org/10.1039/c1rp90072b

Labobar, H., Setyosari, P., Degeng, I. N. S., \& Dasna, I. W. (2017). The effect of cognitive conflict strategy to chemical conceptual change. International Journal of Science and Research (IJSR), 6(4), 2350-2352. https://doi.org/10.21275/ART20172970

Lathifa, U. (2018). Correcting students' misconception in acid and base concept using pdeode instruction strategy. Unnes Science Education Journal, 7(2), 170-177. https://doi.org/10.15294/usej.v7i2.23202

Madu, B. C., \& Orji, E. (2015). Effects of cognitive conflict instructional strategy on students' conceptual change in temperature and heat. SAGE Open, 5(3), 1-9. https://doi.org/10.$1177 / 2158244015594662$

Malone, K. L., Schunn, C. D., \& Schuchardt, A. M. (2018). Improving conceptual understanding and representation skills through Excel-based modeling. Journal of Science Education and Technology, 27(1), 30-44. https://doi.org/10.1007/s10956-017-9706-0

Maysara, M., \& Habiddin, H. (2019). The implementation of reciprocal teaching model to improve students' achievement on acid-base concepts. J-PEK (Jurnal Pembelajaran Kimia), 4(1), 14-17. https://doi.org/10.17977/um026v4i12019p 014

Muchtar, Z. (2012). Analyzing of students' misconceptions on acid-base chemistry at senior high schools in Medan. Journal of Education and Practice, 3(15), 65-74. https://doi.org/10.1177/014616721140042 3.

Ngalimun, N. (2016). Meningkatkan kemampuan berbicara siswa dalam menceritakan kegemaran melalui teknik percakapan. $A l$ Adzka: Jurnal Ilmiah Pendidikan Guru Madrasah Ibtidaiyah, 6(1), 33-42.

Pan, H., \& Henriques, L. (2015). Students' alternate conceptions on acids and bases. School Science and Mathematics, 115(5), 237-243. https://doi.org/10.1111/ssm.12124 
Rahayu, S., Chandrasegaran, A. L., Treagust, D. F., Kita, M., \& Ibnu, S. (2011). Understanding acid-base concepts: Evaluating the efficacy of a senior high school student-centred instructional program in Indonesia. International Journal of Science and Mathematics Education, 9(6), 1439-1458. https://doi.org/10.1007/s10763-010-9272-x

Rohmah, R. S., Fariati, F., \& Ibnu, S. (2020). Effect of conceptual change texts on physical inorganic chemistry students' misconceptions of matter and its changes. AIP Conference Proceedings, 2215(1), 20020. https://doi.org/10.1063/5.0000492

Sendur, G., Toprak, M., \& Pekmez, E. S. (2010). Analyzing of student's misconceptions about chemical equilibrium. International Conference on New Trends in Education and Their Implications, 1-6.

Sreenivasulu, B., \& Subramaniam, R. (2013). University students' understanding of chemical thermodynamics. International Journal of Science Education, 35(4), 601635.
Sreenivasulu, B., \& Subramaniam, R. (2014). Exploring undergraduates' understanding of transition metals chemistry with the use of cognitive and confidence measures. Research in Science Education, 44(6), 801828 .

Suyono, S. (2020). Miskonsepsi kimia, sebuah misteri. J-PEK (Jurnal Pembelajaran Kimia)Jurnal Pembelajaran Kimia, 5(1), 1-7. https://doi.org/http://dx.doi.org/10.17977/um026v5i12020p001

Yan, Y. K., \& Subramaniam, R. (2018). Using a multi-tier diagnostic test to explore the nature of students' alternative conceptions on reaction kinetics. Chemistry Education Research and Practice, 19(1), 213-226. https://doi.org/10.1039/c7rp00143f

Yulianingtyas, E., Budiasih, E., \& Marfuah, S. (2017). Pengaruh penggunaan jurnal belajar dalam model pembelajaran learning cycle 6e terhadap kesadaran metakognitif siswa SMAN 8 Malang pada materi redoks. Jurnal Pendidikan: Teori, Penelitian, Dan Pengembangan, 2(5), 724-730. 